\title{
Genetic Variation and Postflowering Drought Effects on Seed Iron and Zinc in ICRISAT Sorghum Mini Core Collection
}

\author{
Hari D. Upadhyaya,^ Sangam L. Dwivedi, Sube Singh, Kanwar L. Sahrawat, and Shailesh K. Singh
}

\begin{abstract}
Drought stress invariably reduces yield and may alter seed chemistry. This experiment was initiated to characterize the sorghum [Sorghum bicolor (L.) Moench] mini core collection for genetic variation and to study the effect of postflowering drought on seed Fe and Zn concentrations. Accessions with similar maturity, together with controls, were evaluated in split-plot design under irrigated and drought-stressed environments for two postrainy seasons. Residual (or restricted) maximum likelihood (REML) analysis of data considering genotypes as random and drought and year as fixed indicated highly significant variance as a result of genotypes. Highly significant effects of drought $(D)$, year $(Y)$, and $D$ $\times Y$ interaction emphasized need for multilocation evaluation of germplasm for agronomic and seed nutritional traits. About twofold variation in $\mathrm{Fe}\left(25.8-48.9 \mathrm{mg} \mathrm{kg}^{-1}\right.$ seed) and threefold variation in $\mathrm{Zn}$ (13.5-42.6 mg kg-1 seed) concentrations was observed across environments. Eleven accessions with high seed Fe, 14 accessions with high $\mathrm{Zn}$, and nine accessions high in both $\mathrm{Fe}$ and $\mathrm{Zn}$ were identified. These accessions, however, produced low seed yields. In addition, six and four accessions, respectively, showed 8 to $39 \%$ and 9 to $38 \%$ greater Fe and Zn over control IS 33844 and produced seed yields similar to that of IS 33844 . Significant rank correlation $(\geq 0.70)$ indicated that accessions with high $\mathrm{Fe}$ or $\mathrm{Zn}$ under irrigated environments are also expected to perform well under drought-stressed environments. Significantly positive correlation between $\mathrm{Fe}$ and $\mathrm{Zn}$ indicated simultaneous improvement as a realistic approach in breeding. The identified germplasm are ideal genetic resources for the development of $\mathrm{Fe}$ - and $\mathrm{Zn}$-dense sorghum cultivars.
\end{abstract}

H.D. Upadhyaya, S.L. Dwivedi, S. Singh, K.L. Sahrawat, and S.K. Singh, International Crops Research Institute for the Semi-Arid Tropics (ICRISAT), Patancheru, 502 324, Telangana, India. H.D. Upadhyaya, Dep. of Agronomy, Kansas State Univ., Manhattan, KS 66506, USA; H.D. Upadhyaya, UWA Inst. of Agriculture, Univ. of Western Australia, Crawley WA 6009, Australia. Received 19 May 2015. Accepted 6 Aug. 2015. `Corresponding author (h.upadhyaya@cgiar.org).

Abbreviations: D, drought; DAP, days after planting; $G$, genotype; REML, residual (or restricted) maximum likelihood; SSR, simplesequence repeat; $Y$, year.

W IDESPREAD MICRONUTRIENT MALNUTRITION results in an enormous socioeconomic cost to the developing world (Darnton-Hill et al., 2005; Stein, 2010). Iron (Fe) and zinc (Zn) deficiencies in human beings lead to a variety of health-related problems (United Nations System Standing Committee on Nutrition, 2009). Fighting malnutrition is an integral component of three of the eight millennium development goals (http:// en.wikipedia.org/wiki/Millennium_Development_Goals). Biofortification refers to the development of micronutrient-dense staple food crops using traditional breeding or biotechnology (Bouis, 2003). Crop biofortification is a sustainable and cost-effective strategy to address malnutrition arising out of micronutrient deficiency in the developing world. The mineral-dense seeds often produce more viable and vigorous seedlings, and such plants are more efficient in mineral uptake, thus leading to improved stress tolerance and increased crop yields (Welch, 1986; Graham and Welch, 1996; Rengel and Graham, 1995; Cakmak, 2008). Nutritional traits are highly influenced by genotype, environment (location and season), and genotype $\times$ environment interaction, thus necessitating the need to conduct multienvironment evaluations to identify seed mineral-dense germplasm before their use in crop breeding (Dwivedi et al. [2012] and references cited

Published in Crop Sci. 56:1-11 (2016).

doi: 10.2135/cropsci2015.05.0308

(C) Crop Science Society of America | 5585 Guilford Rd., Madison, WI 53711 USA All rights reserved. 
therein). Furthermore, drought stress invariably leads to rise in air and soil temperatures, which affect soil or seed chemistry or both, alone, or in conjunction with drought effects (Dwivedi et al. [2013] and references cited therein).

Sorghum is a $\mathrm{C}_{4}$ multipurpose crop with high photosynthetic efficiency and mostly grown for food, feed, and fuel. Sorghum is the fifth most important cereal after maize (Zea mays L.), rice (Oryza sativa L.), wheat (Triticum aestivum L.), and barley (Hordeum vulgare L.). Annual average contribution to the global cereal production $(2570.7$ $\mathrm{Tg}$ ) by sorghum during 2009 through 2013 was $58.7 \mathrm{Tg}$, with Africa, America, Asia, and Oceania contributing 24.3, 21.6, 9.8, and 2.1 Tg, respectively (FAOSTAT, 2013). The major sorghum producing countries are Nigeria, Ethiopia, former Sudan, Burkina Faso, Mali, Cameroon, and Niger in Africa; United States, Mexico, Argentina, and Brazil in America; India and China in Asia; and Australia in Oceania. Worldwide, sorghum is largely grown during the rainy season in the semiarid tropical areas of Africa and Asia, which is often characterized by increasing moisture stress, causing increasing plant stress as the season progresses. Eighty percent of sorghum production in the world is under dryland conditions. Sorghum is more drought tolerant than any other cereal crop. The drought response by sorghum, however, is not without yield penalty. Drought stress at the vegetative stage is reported to reduce yield more than $36 \%$, while stress at the reproductive stage reduces yield more than 55\% (Assefa et al., 2010). India is the largest producer of sorghum $(\sim 3 \mathrm{Tg}$ from 5.7 million ha) grown during the postrainy season (September-October to March-April), and postflowering drought is common, as the crop relies largely on soil moisture stored during the preceding rainy season (Kholová et al., 2012).

Natural variation in plant genetic resources for agronomically beneficial traits is a key to success in crop improvement programs. The evidence to date suggests substantial genetic variation for $\mathrm{Fe}$ and $\mathrm{Zn}$ in germplasm collections to develop seed micronutrient dense food crops. For example, $\mathrm{Fe}$ and $\mathrm{Zn}$ concentrations in sorghum germplasm, respectively, ranged from 11.5 to 54.4 and 13.5 to $34.7 \mathrm{mg} \mathrm{kg}^{-1}$ dry seed in Ethiopia (Shegro et al., 2012), 30 to 113 and 11 to $44 \mathrm{mg} \mathrm{kg}^{-1}$ dry seed in Benin (Kayodé et al., 2006), and 24 to 73 and 15 to $59 \mathrm{mg} \mathrm{kg}^{-1}$ seed in the United States (Waters and Pedersen, 2009). The genebank at the ICRISAT (International Crops Research Institute for the Semi-Arid Tropics) in Patancheru, India holds 38,675 sorghum germplasm, including wild and weedy relatives (www.icrisat.org). To date, limited germplasm, including cultivars, have been screened, and variation for $\mathrm{Fe}$ and $\mathrm{Zn}$ among these select germplasm and cultivars, respectively, ranged from 26 to 61 and 17 to $57 \mathrm{mg} \mathrm{kg}^{-1}$ seed (Kumar et al., 2012). Representative germplasm subsets, such as core (Frankel, 1984) and mini core (Upadhyaya and Ortiz, 2001) collections, which represent the diversity of the entire collection of a given species preserved in a genebank, are ideal genetic resources for identifying new sources of variations for agronomically beneficial traits (Upadhyaya et al., 2013, 2014b).

This study was initiated (i) to determine genetic variation and the effect of postflowering drought stress on seed $\mathrm{Fe}$ and $\mathrm{Zn}$ concentrations in a sorghum mini core collection (Upadhyaya et al., 2009) and (ii) to identify genetically diverse germplasm for use in crop improvement programs that produce nutritionally dense (Fe and $\mathrm{Zn}$ ) seeds with agronomically beneficial traits.

\section{MATERIALS AND METHODS Experimental Details}

The material evaluated consisted of 242 sorghum mini core collection accessions from 58 countries (Upadhyaya et al., 2009) and three controls. The mini core collection accessions include both the five basic sorghum races (caudatum 16.1\%, durra $12.4 \%$, guinea $12 \%$, kafir $8.7 \%$, and bicolor $8.3 \%$ ) and their 10 hybrid derivative or intermediate races (caudatum-bicolor 12.4\%; guinea-caudatum 11.2\%; durra-caudatum 7.9\%; durra-bicolor, and kafir-caudatum each 2.9\%; kafir-durra 1.7\%; guinea-kafir 1.2\%; and guinea-bicolor, guinea-durra, and kafir-bicolor each 0.8\%) (Upadhyaya et al., 2009). The controls included in this study were IS 2205, IS 18758, and IS 33844; among these, IS 33844 is the most popular sorghum cultivar widely grown under receding soil moisture conditions during rabi (postrainy) season in India, while IS 18758 is cultivated in Burkina Faso and Burundi (Upadhyaya et al., 2014a). IS 33844 has exceptionally high plasticity to perform well under varied environments or varying times; it is tolerant to terminal drought and possesses excellent seed quality attributes (ICRISAT unpublished work, 2009).

The experiment was conducted at Patancheru $\left(78^{\circ} 12^{\prime} \mathrm{E}\right.$, $17^{\circ} 24^{\prime} \mathrm{N}$, and $545 \mathrm{~m}$ asl), India, in precision fields on Vertisol Kasireddipally series-isohypothermic Typic Pellustert (El-Swaify et al., 1985) in a split-plot design in three replications using drought stress and control (fully irrigated) treatments as the main plot and genotypes as the subplots in five maturity groups (Group 1, flowered $\leq 60 \mathrm{~d}$ after planting [DAP]; Group 2, flowered 61-70 DAP; Group 3, flowered 71-80 DAP; Group 4, flowered 81-90 DAP; and Group 5, flowered >90 DAP) during the 2010 to 2011 and 2011 to 2012 postrainy seasons. Days to $50 \%$ flowering observations recorded during 2009 to 2010 postrainy season at Patancheru was used to group the accessions at $10-\mathrm{d}$ interval into five maturity groups. The experimental fields in both the years were fallow during the rainy seasons. The precision fields at the ICRISAT center have irrigation facilities with gentle slope $(0.5 \%)$, have uniform fertility, and the concentrations of DTPA (diethylene triaminepentaacetic acid) extractable Fe and Zn (Lindsay and Norvell, 1978) in the soil in these fields are maintained greater than the critical limits $\left(2.0 \mathrm{mg} \mathrm{kg}^{-1}\right.$ for Fe and $0.75 \mathrm{mg} \mathrm{kg}^{-1}$ soil for $\mathrm{Zn)}$ (KL Sahrawat, ICRISAT, personal communication, 2010). The experiment was sow $n$ in the second week of October each year and harvested in April of the following years. The minimum monthly average temperature during postrainy seasons at Patancheru ranged from 10.9 to $22.8^{\circ} \mathrm{C}$, while the maximum 
monthly average temperature ranged from 27.3 to $37.5^{\circ} \mathrm{C}$. The cumulative rainfall during the crop season was $23.9 \mathrm{~mm}$ in 2010 to 2011 and $41.0 \mathrm{~mm}$ in 2011 to 2012 . The average daylength was $11.64 \mathrm{~h}$ (range 11.08-12.75 h) each year. Plot size consisted of one row of $4 \mathrm{~m}$, with an inter- and intrarow spacing of 75 and $10 \mathrm{~cm}$, respectively. Seeds were sown at uniform depth, and crop specific agronomic practices, including plant protection, were followed. Ammonium phosphate was applied at the rate of $150 \mathrm{~kg} \mathrm{ha}^{-1}$ as a basal dose, while urea was applied at the rate of $100 \mathrm{~kg} \mathrm{ha}^{-1}$ as top-dressing 3 wk after planting. Ridge and furrow system of cultivation was adapted, and each time the experimental plots received about $7 \mathrm{~cm}$ of irrigation water. The fully irrigated plots received five irrigations in total, while the plots with limited irrigation (water-stressed environment) received one to four irrigations depending on the maturity group of the accessions. To simulate drought-stressed environment, irrigation was stopped at 25 DAP in Group 1, 37 DAP in Group 2, 47 DAP in Group 3, 57 DAP in Group 4, and 66 DAP in Group 5. Days to 50\% flowering was recorded per plot, while observations on plant height $(\mathrm{cm})$, head length $(\mathrm{cm})$, and head width $(\mathrm{cm})$ on five plants were measured at maturity (IBPGR and ICRISAT, 1993). Grain yield (g plant ${ }^{-1}$ ) was recorded on five representative plants. One hundred sound mature seeds were weighed to record observation on 100-seed weight (g).

\section{Seed Chemical Analysis}

Precautions were taken to avoid the contamination of seeds with dust and metal particles during harvest and while preparing them for analysis. Further, the seed samples were washed in distilled water and oven-dried at $60^{\circ} \mathrm{C}$ for $48 \mathrm{~h}$ before grinding. The dried-seed samples $(20 \mathrm{~g})$ from each replication were then powdered in a mill with Teflon chambers and ground samples kept overnight in an oven at $60^{\circ} \mathrm{C}$. The standards and samples were digested simultaneously with appropriate blanks in duplicate (two independent analyses). One gram of ground sample was transferred to digestion tube $(75 \mathrm{~mL}$ capacity and $10 \mathrm{~mL}$ of tri-acid mixture consisting of nitric acid, sulfuric and perchloric acid in the ratio of 10:0.5:2 [v/v]) and the contents left overnight for cold digestion in a digestion chamber. The samples were digested initially at $120^{\circ} \mathrm{C}$ for $1 \mathrm{~h}$, followed by digestion at $230^{\circ} \mathrm{C}$ for about $2 \mathrm{~h}$ to get clear and colorless digests. Following cooling of the digests, the contents were dissolved in distilled water and volume made to $75 \mathrm{~mL}$ and contents shaken well. Aliquots were taken from the digests and analyzed for $\mathrm{Fe}$ and $\mathrm{Zn}$ concentrations ( $\mathrm{mg} \mathrm{kg}^{-1}$ ) by atomic absorption spectrophotometry (Varian Spectra AA 20, Sahrawat et al., 2002). The concentration of $\mathrm{Fe}$ and $\mathrm{Zn}$ were estimated and expressed as milligrams per kilogram of seed.

\section{Statistical and Diversity Analysis}

In spite of grouping of sorghum mini core collection accessions based on a priori knowledge of phenology (flowering), days to $50 \%$ flowering on 26 accessions (eleven in Group 1, eight in Group 2, three in Group 3, and four in Group 4) during the two postrainy seasons (2010-2011 and 2011-2012) exceeded the flowering duration fixed for each group and were consid ered as outliers and removed before statistical analysis.
Data were analyzed using REML (Patterson and Thompson, 1971) in GenStat 14.1 software (VSN International, 2013). The replication-wise values of various traits in each maturity group in each year were used for statistical analysis considering genotypes $(G)$ as random and $D$ as fixed. Variance components of genotypes $\left(\sigma_{\mathrm{g}}^{2}\right)$ and error $\left(\sigma_{\mathrm{e}}^{2}\right)$, and their standard errors (SE) were determined. Best linear unbiased predictors for the genotypes were calculated. The significance of the $\sigma_{\mathrm{g}}^{2}$ was tested using its SE. For the pooled REML analysis, $G$ was considered random and $Y$ and $D$ as fixed. The variance from genotypes $\left(\sigma_{\mathrm{g}}^{2}\right)$, and $G \times Y\left(\sigma_{\mathrm{g} \times \mathrm{y}}^{2}\right), G \times D\left(\sigma_{\mathrm{g} \times \mathrm{d}}^{2}\right), G$ $\times D \times Y\left(\sigma^{2}{ }_{\mathrm{g} \times \mathrm{d} \times \mathrm{y}}\right)$ interactions and their standard errors were determined. The significance of the $Y, D$, and their interaction was assessed using the Wald (1943) statistic that asymptotically follows a $\chi^{2}$ distribution. Best linear unbiased predictors based on pooled analysis of two seasons' data were obtained and used for further analysis. Dunnett's procedure (Dunnett, 1964) was used to test significance of differences between the means of irrigated and drought-stressed environments within each maturity group. Rank correlation, which is a nonparametric measure of association based on the ranks of the data values, was estimated using the ranks (Spearman, 1904).

The mini core collection accessions (242) are a subset of the sorghum composite collection (3367 accessions), which were molecularly profiled using 41 polymorphic simple-sequence repeats (SSRs) for dissecting population structure and diversity in composite collection (Billot et al., 2013). Identifying genetically diverse germplasm with agronomically beneficial traits is needed to support crop breeding. Forty-one SSR data points on the selected 34 accessions (high in seed Fe and $\mathrm{Zn}$ ) together with controls were subjected to DARwin-5.0 (Perrier et al., 2003) structure analysis to derive simple matching allele frequency-based distance matrix, which was later used to identify genetically diverse pairs (accessions) with agronomically beneficial traits. The published information was used to relate if any of the seed-nutrient dense accessions identified in this study are also reported resistant to major pest and diseases.

\section{RESULTS}

\section{Variance in Relation to Trait Expression}

The REML analysis of 2010 to 2011 and 2011 to 2012 season data revealed significant genotypic variance $\left(\sigma^{2}\right.$ ) for seed $\mathrm{Fe}$ and $\mathrm{Zn}$ concentrations, days to 50\% flowering, head length and width, seed yield per plant, and 100-seed weight in Groups 1 to 4 (data not given). In Group 5, $\sigma_{\mathrm{g}}^{2}$ was significant for days to $50 \%$ flowering, head length, and 100-seed weight in both the seasons. The significant Wald statistic indicated the influence of drought for most of the traits in Groups 1 to 4 in both seasons (data not given). In pooled analysis, $\sigma_{\mathrm{g}}^{2}$ was significant for all the traits in all the five groups except Fe and $\mathrm{Zn}$ concentrations and for head width and seed yield per plant in Group 5. Variance as a result of $G \times D\left(\sigma_{\mathrm{g} \times \mathrm{d}}^{2}\right)$ was significant for only) $\overline{Z n}$ concentration in Group $3 ; G \times Y\left(\sigma_{g \times y}^{2}\right)$ for $\mathrm{Zn}$, days to $50 \%$ flowering, head length, and 100-seed weight in Groups 1 and 2; head width in Group 1; days to 50\% 
Table 1. Estimates of variance from genotype $\left(\sigma^{2}\right)$, genotype $\times$ drought $\left(\sigma^{2}{ }_{g \times d}\right)$, genotype $\times$ year $\left(\sigma^{2}{ }_{g \times y}\right)$, genotype $\times$ drought $\times$ year $\left(\sigma^{2}{ }_{g \times d \times y}\right)$ interactions and Wald statistics for drought $(d)$, year $(y)$ and $d \times y$ for seed Fe and Zn concentrations ( $m g$ $\mathrm{kg}^{-1} \mathrm{seed}$ ) and agronomic traits in the five groups of sorghum mini core collection accessions evaluated under irrigated and drought-stressed environments during the 2010-2011 and 2011-2012 postrainy seasons, Patancheru, India.

\begin{tabular}{|c|c|c|c|c|c|c|c|}
\hline \multirow[b]{2}{*}{ Trait } & \multirow[b]{2}{*}{$\sigma_{g}^{2}$} & \multirow[b]{2}{*}{$\sigma_{g \times d}^{2}$} & \multirow[b]{2}{*}{$\sigma_{g \times y}^{2}$} & \multirow[b]{2}{*}{$\sigma_{g \times d \times y}^{2}$} & \multicolumn{3}{|c|}{ Wald statistics } \\
\hline & & & & & $d$ & $y$ & $d \times y$ \\
\hline \multicolumn{8}{|c|}{ Group 1 (25 entries including controls) } \\
\hline $\mathrm{Fe}\left(\mathrm{mg} \mathrm{kg}^{-1}\right.$ seed $)$ & $25.8^{\star *}$ & 3.7 & 3.4 & $7.5^{\star}$ & $90.8^{* *}$ & $221.7^{\star \star}$ & $32.3^{\star *}$ \\
\hline Zn (mg kg ${ }^{-1}$ seed $)$ & $31.7^{\star \star}$ & 3.0 & $4.3^{*}$ & 2.2 & $100.6^{\star \star}$ & $126.2^{\star \star}$ & $21.4^{\star \star}$ \\
\hline Days to $50 \%$ flowering & $45.7^{\star \star}$ & 0.04 & $9.5^{\star \star}$ & $3.8^{\star *}$ & $4.2^{*}$ & $6.0^{*}$ & 0.6 \\
\hline Head length (cm) & $27.8^{\star \star}$ & 0.2 & $2.0^{*}$ & 0.3 & $43.4^{\star \star}$ & $7.5^{\star \star}$ & $101.1^{\star *}$ \\
\hline Head width (cm) & $20.0^{\star \star}$ & 0.6 & $1.4^{*}$ & $1.2^{* *}$ & $20.7^{\star \star}$ & $5.6^{*}$ & $62.7^{\star *}$ \\
\hline Seed yield plant ${ }^{-1}(\mathrm{~g})$ & $47.6^{\star \star}$ & 2.6 & 4.3 & $15.3^{\star \star}$ & $36.0^{\star \star}$ & $46.8^{\star \star}$ & $18.1^{\star *}$ \\
\hline 100-seed weight (g) & $0.3^{\star \star}$ & $<0.01$ & $0.05^{\star *}$ & $0.03^{*}$ & $13.5^{\star \star}$ & $32.2^{\star *}$ & $103.3^{* *}$ \\
\hline \multicolumn{8}{|c|}{ Group 2 (77 entries including controls) } \\
\hline $\mathrm{Fe}\left(\mathrm{mg} \mathrm{kg}^{-1}\right.$ seed) & $20.1^{\star \star}$ & 1.1 & 0.5 & $13.4^{\star \star}$ & $167.5^{\star \star}$ & $657.7^{\star \star}$ & $61.4^{\star *}$ \\
\hline Zn (mg kg ${ }^{-1}$ seed) & $20.4^{\star \star}$ & 0.5 & $3.4^{*}$ & $5.7^{\star \star}$ & $278.6^{\star \star}$ & $520.6^{* \star}$ & $168.6^{\star \star}$ \\
\hline Days to $50 \%$ flowering & $21.2^{\star *}$ & 0.5 & $6.8^{\star \star}$ & $3.9^{\star *}$ & $15.9^{* \star}$ & $64.6^{\star \star}$ & $22.7^{\star *}$ \\
\hline Head length (cm) & $31.4^{\star *}$ & 0.3 & $0.9^{\star \star}$ & $1.1^{\star \star}$ & $22.6^{\star \star}$ & $25.1^{\star \star}$ & $120.4^{\star *}$ \\
\hline Head width (cm) & $13.0^{\star \star}$ & 0.1 & 0.5 & $15.5^{\star \star}$ & 3.1 & $28.6^{\star \star}$ & $70.1^{\star \star}$ \\
\hline Seed yield plant ${ }^{-1}(\mathrm{~g})$ & $39.8^{\star \star}$ & 1.4 & 1.0 & $5.1^{\star \star}$ & $77.4^{\star *}$ & $10.9^{\star \star}$ & $55.8^{* *}$ \\
\hline 100-seed weight (g) & $0.5^{\star}$ & 0.01 & $0.03^{\star *}$ & $0.04^{\star \star}$ & $44.2^{\star \star}$ & $137.5^{\star \star}$ & $103.0^{* \star}$ \\
\hline \multicolumn{8}{|c|}{ Group 3 (88 entries including controls) } \\
\hline $\mathrm{Fe}\left(\mathrm{mg} \mathrm{kg}^{-1}\right.$ seed $)$ & $11.2^{\star \star}$ & 1.1 & 0.5 & $16.3^{\star *}$ & $259.5^{\star \star}$ & $527.8^{\star \star}$ & $67.1^{\star *}$ \\
\hline $\mathrm{Zn}\left(\mathrm{mg} \mathrm{kg}{ }^{-1}\right.$ seed $)$ & $9.5^{\star \star}$ & $3.2^{*}$ & 0.2 & $6.2^{\star \star}$ & $184.9^{\star \star}$ & $637.4^{\star \star}$ & $91.6^{\star \star}$ \\
\hline Days to $50 \%$ flowering & $17.1^{\star *}$ & 0.4 & $16.6^{\star *}$ & $3.6^{\star \star}$ & $46.0^{\star *}$ & $79.0^{\star \star}$ & 1.2 \\
\hline Head length (cm) & $58.5^{\star *}$ & 1.4 & 1.0 & $3.1^{* \star}$ & $12.5^{\star \star}$ & $17.5^{\star \star}$ & $28.9^{* *}$ \\
\hline Head width (cm) & $17.8^{\star \star}$ & 0.1 & $5.0^{\star \star}$ & $2.7^{\star \star}$ & $15.0^{\star \star}$ & $5.1^{*}$ & $56.6^{\star \star}$ \\
\hline Seed yield plant ${ }^{-1}(\mathrm{~g})$ & $48.6^{\star \star}$ & 2.1 & $8.4^{\star \star}$ & $8.8^{\star *}$ & $111.2^{\star \star}$ & $11.3^{\star \star}$ & $46.3^{\star *}$ \\
\hline 100-seed weight (g) & $0.7^{\star \star}$ & 0.01 & $0.3^{\star \star}$ & $0.3^{\star \star}$ & $12.0^{\star \star}$ & $85.6^{\star \star}$ & $97.0^{* \star}$ \\
\hline \multicolumn{8}{|c|}{ Group 4 (30 entries including controls) } \\
\hline $\mathrm{Fe}\left(\mathrm{mg} \mathrm{kg}^{-1}\right.$ seed $)$ & $16.3^{\star \star}$ & 0.7 & 3.8 & $16.2^{*}$ & $55.8^{\star *}$ & $254.7^{\star \star}$ & $28.1^{\star *}$ \\
\hline Zn (mg kg ${ }^{-1}$ seed) & $15.2^{\star \star}$ & 0.3 & 2.1 & 3.3 & $41.2^{\star *}$ & $198.9^{\star \star}$ & $52.7^{\star *}$ \\
\hline Days to $50 \%$ flowering & $40.0^{\star \star}$ & 0.01 & $11.3^{\star \star}$ & $1.81^{\star \star}$ & 1.2 & $54.3^{\star \star}$ & $7.7^{\star \star}$ \\
\hline Head length (cm) & $40.4^{\star \star}$ & 0.2 & $3.2^{\star \star}$ & 0.2 & $5.8^{*}$ & $4.3^{*}$ & $9.5^{\star \star}$ \\
\hline Head width (cm) & $3.6^{\star \star}$ & 0.07 & $3.8^{\star \star}$ & $1.1^{*}$ & $6.3^{*}$ & $12.3^{\star \star}$ & 2.6 \\
\hline Seed yield plant ${ }^{-1}(\mathrm{~g})$ & $67.4^{\star \star}$ & 2.9 & 4.9 & $11.3^{\star \star}$ & $17.0^{\star \star}$ & $18.1^{\star \star}$ & $6.5^{\star}$ \\
\hline 100-seed weight (g) & $0.4^{\star \star}$ & $<0.01$ & 0.01 & $0.02^{\star \star}$ & $15.4^{\star \star}$ & $7.3^{\star \star}$ & $51.7^{\star \star}$ \\
\hline \multicolumn{8}{|c|}{ Group 5 (11 entries including controls) } \\
\hline $\mathrm{Fe}\left(\mathrm{mg} \mathrm{kg}^{-1}\right.$ seed $)$ & 8.7 & 10.2 & 6.3 & 1.5 & $4.5^{\star}$ & $40.8^{\star \star}$ & $46.5^{\star \star}$ \\
\hline Zn (mg kg ${ }^{-1}$ seed) & 23.3 & 0.8 & 1.9 & 4.5 & 3.6 & $27.2^{\star *}$ & $12.6^{\star \star}$ \\
\hline Days to $50 \%$ flowering & $171.6^{\star \star}$ & 3.4 & $32.7^{\star}$ & 1.7 & 1.4 & $15.6^{\star \star}$ & 0.7 \\
\hline Head length (cm) & $34.8^{*}$ & 0.4 & 2.1 & 1.9 & 1.8 & 0.6 & $12.2^{\star *}$ \\
\hline Head width (cm) & 22.8 & 0.3 & 1.4 & $8.3^{*}$ & 2.4 & 3.5 & 3.9 \\
\hline Seed yield plant ${ }^{-1}(\mathrm{~g})$ & 72.1 & 26.9 & 12.1 & 0.7 & 3.3 & $21.5^{\star \star}$ & 0.1 \\
\hline 100-seed weight (g) & $0.4^{*}$ & 0.01 & 0.05 & 0.03 & 0.1 & $6.7^{*}$ & $16.2^{\star \star}$ \\
\hline
\end{tabular}

* Significant at the 0.05 probability level.

** Significant at the 0.01 probability level.

flowering, head width, seed yield, and 100-seed weight in Group 3; days to 50\% flowering, head length, and head width in Group 4; and days to 50\% flowering and 100seed weight in Group 5 (Table 1). Variance as a result of $G \times D \times Y\left(\sigma_{\mathrm{g} \times \mathrm{d} \times \mathrm{y}}^{2}\right)$ was significant for all the traits in Groups 2 and 3 and $\mathrm{Fe}$, days to $50 \%$ flowering, head width, seed yield, and seed weight in Groups 1 and 4. In Group $5, \sigma_{\mathrm{g} \times \mathrm{d} \times \mathrm{y}}^{2}$ was significant only for head width (Table 1 ).
Effects of $D, Y$ and $D \times Y$ were significant for all the traits in Groups 1 to 4 , except effect of $D$ for head width in Group 2 and days to $50 \%$ flowering in Group 4 and $D \times Y$ for days to $50 \%$ flowering in Group 1 and Group 3 and head width in Group 4 (Table 1). Both Fe and Zn concentrations relative to irrigated control increased significantly under drought-stressed environments in Groups 1 to 4 (Table 2). The increase ranged from 20.5 to $28.5 \%$. 
Table 2. Effects of drought stress on seed Fe and Zn concentrations ( $\mathrm{mg} \mathrm{kg}^{-1}$ seed), seed yield (g) and 100-seed weight (g) in five maturity groups of sorghum mini core collection accessions evaluated under irrigated and drought-stressed environments during the 2010-2011 and 2011-2012 postrainy seasons, Patancheru, India.

\begin{tabular}{|c|c|c|c|c|}
\hline \multirow[b]{2}{*}{ Group $^{\dagger}$} & \multicolumn{2}{|c|}{ Fe concentration } & \multicolumn{2}{|c|}{ Zn concentration } \\
\hline & Irrigated & Drought & Irrigated & Drought \\
\hline & \multicolumn{4}{|c|}{$\mathrm{mg} \mathrm{kg}^{-1}$ seed $\longrightarrow$} \\
\hline Group 1 & 32.2 & $41.2^{*}$ & 24.1 & $29.9^{\star}$ \\
\hline Group 2 & 32.2 & $38.8^{*}$ & 23.6 & $29.5^{\star}$ \\
\hline Group 3 & 30.2 & $38.8^{*}$ & 21.8 & $27.5^{\star}$ \\
\hline Group 4 & 30.8 & $37.2^{*}$ & 24.6 & $27.5^{\star}$ \\
\hline \multirow[t]{4}{*}{ Group 5} & 32.3 & 35.7 & 24.7 & 27.0 \\
\hline & \multicolumn{2}{|c|}{ Seed yield } & \multicolumn{2}{|c|}{ 100-seed weight } \\
\hline & Irrigated & Drought & Irrigated & Drought \\
\hline & \multicolumn{2}{|c|}{ - g plant $^{-1} \longrightarrow$} & \multicolumn{2}{|c|}{$-g-$} \\
\hline Group 1 & 18.7 & 15.3 & 2.7 & 2.5 \\
\hline Group 2 & 23.4 & $19.5^{\star}$ & 2.5 & 2.3 \\
\hline Group 3 & 26.1 & $21.3^{*}$ & 2.5 & 2.4 \\
\hline Group 4 & 25.1 & 21.9 & 2.3 & 2.2 \\
\hline Group 5 & 24.0 & 19.1 & 2.2 & 2.2 \\
\hline
\end{tabular}

* Significant at the 0.05 probability level. Dunnett's $t$-test was used to test significance of differences in means between irrigated and drought-stressed environments.

† Group 1, flowered $\leq 60$ d after planting [DAP]; Group 2, flowered between 61 and 70 DAP; Group 3, flowered between 71 and 80 DAP; Group 4, flowered between 81 and 90 DAP; Group 5, flowered >90 DAP;

Drought stress significantly reduced seed yield in Group 2 and 3 only, while it had no effect on 100-seed weight in any group (Table 2).

\section{Spearman Rank Correlations}

Seed Fe (except for Group 5) under irrigated environments was significantly and positively associated with $\mathrm{Fe}$ under drought-stressed environments. Likewise, seed $\mathrm{Zn}$ under irrigated environments was also significantly and positively associated with $\mathrm{Zn}$ under drought-stressed environments. In addition, the correlation between $\mathrm{Fe}$ and $\mathrm{Zn}$ was positive and significant in each environment (Table 3). Seed yield and seed weight were strongly and positively associated under irrigated and drought-stressed environments. In contrast, both seed yield and seed weight were either not related or negatively correlated with seed $\mathrm{Fe}$ and $\mathrm{Zn}$ under irrigated and drought-stressed environments (Table 3).

\section{Variability for Seed Iron and Zinc and Agronomic Traits}

A comparison of the performance of controls across the groups revealed that IS 18758 and IS 2205, respectively, are the best controls for use to identify the best performing accessions in terms of high $\mathrm{Fe}$ and $\mathrm{Zn}$ concentrations in each group. The seed Fe in IS 18758 and $\mathrm{Zn}$ in IS 2205 ranged from 29.6 to 34.1 and 23.9 to $25.7 \mathrm{mg} \mathrm{kg}{ }^{1}$ seed in Group 1 to 5 , respectively, and these values were always greater than that in other controls used in this study (Table
4). A number of accessions with significantly greater $\mathrm{Fe}$ and $\mathrm{Zn}$ than that of IS 18758 (for Fe) and IS 2205 (for Zn) were identified across the environments. For example, 11 accessions with significantly greater $\mathrm{Fe}, 14$ accessions with significantly greater $\mathrm{Zn}$, and nine accessions with significantly greater $\mathrm{Fe}$ and $\mathrm{Zn}$ than that in controls (Fe, IS 18758; Zn, IS 2205) were identified (Table 4; Supplementary Table S1 for performance and ranking of accessions in irrigated and drought-stressed environments and pooled across environments). The increase in seed Fe among these accessions over IS 18758 ranged from 31.3 to $64.2 \%$, while $\mathrm{Zn}$ over IS 2205 ranged from 27.2 to $68.6 \%$ (data not presented).

Amongst the controls, IS 33844 was the most consistent for high seed yield in each maturity group (Table 4). The average seed yield of IS 33844 across environments ranged from 33.5 to $42.4 \mathrm{~g} \mathrm{plant}^{-1}$ in Groups 1 to 5, while minor variation in seed weight (3.4-3.6 g) was noted across environments and Groups. For seed yield and 100-seed weight, none of the accessions with high seed $\mathrm{Fe}$ or $\mathrm{Zn}$ concentrations, were comparable to IS 33844. In addition, six (IS 1004, 23514, 23579, 23590, 28141, and 31706) and four (IS 1004, 27034, 28141, and 31706) accessions, respectively, showed 8 to 39 and 9 to $38 \%$ greater Fe and $\mathrm{Zn}$ over IS 33844 and produced seed yields similar to that of IS 33844 (data not presented).

\section{Genetic Diversity}

Marker-based genetic distance between accessions, based on simple matching allele frequency-based distance matrix, was used to identify genetically diverse pairs with large variation in seed $\mathrm{Fe}$ and $\mathrm{Zn}$ concentrations. The genetic distance among 666 pairwise comparisons (based on 37 accessions including controls) ranged from 0.225 to 0.947 and averaged 0.655 (Supplementary Table S2). A number of genetically diverse pairs of accessions with high seed Fe and Zn concentration were identified. For example, IS 24503 with IS 1212, 1219, 1233, 30383, and 30450, all involving high Fe (41-48 mg kg${ }^{-1}$ seed) and Zn (33-43 mg kg ${ }^{-1}$ seed) accessions and genetic distance ranging between 0.789 and 0.833 . Also, genetically diverse pairs of accessions with high Zn (33-43 $\mathrm{mg} \mathrm{kg}^{-1}$ seed) and low Zn (23-27 $\mathrm{mg} \mathrm{kg}^{-1}$ seed) were identified for use in mapping. These were IS 6382 and IS 1212, IS 1219 and IS 6382, IS 28389 and IS 24503, and IS 1233 with IS 1863 and 16382. The genetic distance for these pairs ranged from 0.625 and 0.808 .

\section{DISCUSSION}

\section{Effect of Drought on Seed Iron and Zinc Concentration}

Plants in the drought-stressed plots in relation to control (well irrigated) suffered severe leaf drying as evident, for example, An case of IS 25836 in Group 2 (Fig. 1), with similar trends noted in all the accessions. This shows that intensity of drought stress was uniform across all the five 
Table 3. Spearman correlation coefficients of seed Fe and $\mathrm{Zn}$ concentration ( $\mathrm{mg} \mathrm{kg}^{-1}$ seed), seed yield (g) and 100-seed weight $(\mathrm{g})$ in five maturity groups of sorghum mini core collection accessions evaluated under irrigated and drought-stressed environments during the 2010-2011 and 2011-2012 postrainy seasons, Patancheru, India.

\begin{tabular}{|c|c|c|c|c|c|}
\hline \multirow[b]{2}{*}{ Trait or environment } & \multicolumn{5}{|c|}{ Spearman rank correlation coefficient } \\
\hline & Group 1 & Group 2 & Group 3 & Group 4 & Group 5 \\
\hline \multicolumn{6}{|l|}{ Seed Fe and Zn } \\
\hline Fe under irrigated and drought-stressed conditions & $0.69^{* *}$ & $0.56^{\star *}$ & $0.48^{* *}$ & $0.53^{\star *}$ & 0.28 \\
\hline Zn under irrigated and drought-stressed conditions & $0.90^{\star \star}$ & $0.80^{* *}$ & $0.55^{\star \star}$ & $0.75^{\star \star}$ & $0.71^{\star}$ \\
\hline Fe and $\mathrm{Zn}$ under irrigated condition & $0.64^{\star \star}$ & $0.72^{\star \star}$ & $0.70^{* *}$ & $0.64^{\star \star}$ & $0.81^{\star *}$ \\
\hline Fe and Zn under drought-stressed condition & $0.74^{\star \star}$ & $0.74^{\star \star}$ & $0.69^{\star \star}$ & $0.71^{\star \star}$ & $0.69^{*}$ \\
\hline \multicolumn{6}{|l|}{ Seed yield with seed $\mathrm{Fe}$ and $\mathrm{Zn}$} \\
\hline Fe and seed yield under irrigated condition & -0.38 & $-0.57^{\star \star}$ & $-0.41^{\star \star}$ & $-0.60^{* *}$ & -0.33 \\
\hline Fe and seed yield under drought stress condition & $-0.41^{*}$ & $-0.57^{\star \star}$ & $-0.32^{\star \star}$ & $-0.55^{\star \star}$ & -0.59 \\
\hline $\mathrm{Zn}$ and seed yield under irrigated condition & -0.08 & $-0.49^{\star \star}$ & $-0.24^{\star}$ & $-0.59^{\star *}$ & -0.26 \\
\hline Zn and seed yield under drought stress condition & -0.13 & $-0.47^{\star \star}$ & $-0.29^{\star *}$ & $-0.42^{*}$ & -0.54 \\
\hline \multicolumn{6}{|l|}{ Seed weight with seed $\mathrm{Fe}$ and $\mathrm{Zn}$} \\
\hline Fe and 100-seed weight under irrigated condition & -0.14 & $-0.31^{\star \star}$ & -0.10 & $-0.53^{\star \star}$ & -0.01 \\
\hline Fe and 100-seed weight under drought stress condition & -0.18 & $-0.45^{\star \star}$ & -0.10 & $-0.51^{\star \star}$ & $-0.64^{*}$ \\
\hline Zn and 100 -seed weight under irrigated condition & $-0.46^{\star}$ & $-0.46^{\star *}$ & -0.13 & $-0.47^{\star *}$ & 0.06 \\
\hline Zn and 100-seed weight under drought stress condition & $-0.47^{\star}$ & $-0.43^{\star \star}$ & -0.18 & -0.23 & -0.25 \\
\hline \multicolumn{6}{|l|}{ Seed yield and seed weight } \\
\hline Seed yield under irrigated and drought-stressed conditions & $0.76^{\star *}$ & $0.87^{\star \star}$ & $0.80^{\star *}$ & $0.83^{\star *}$ & $0.61^{\star}$ \\
\hline Seed weight under irrigated and drought-stressed conditions & $0.95^{\star *}$ & $0.97^{\star *}$ & $0.98^{\star \star}$ & $0.95^{\star *}$ & $1.00^{\star *}$ \\
\hline
\end{tabular}

* Significant at the 0.05 probability level.

** Significant at the 0.01 probability level.

Table 4. Average performance of sorghum mini core collection accessions selected for significantly greater Fe and $\mathrm{Zn}$ concentrations ( $\mathrm{mg} \mathrm{kg}^{-1}$ seed) in terms of days to $50 \%$ flowering, head length, head width, seed yield, and 100 -seed weight under irrigated and drought-stressed environments during the 2010-2011 and 2011-2012 postrainy seasons, Patancheru, India.

\begin{tabular}{|c|c|c|c|c|c|c|c|c|c|}
\hline $\begin{array}{l}\text { Accession } \\
\text { (IS) }\end{array}$ & Race & Origin & $\mathrm{Fe}$ & $\mathrm{Zn}$ & $\begin{array}{l}\text { Seed } \\
\text { yield }\end{array}$ & $\begin{array}{c}100 \text {-seed } \\
\text { weight }\end{array}$ & $\begin{array}{c}\text { Days } \\
\text { to } 50 \% \\
\text { flowering }\end{array}$ & $\begin{array}{l}\text { Head } \\
\text { length }\end{array}$ & $\begin{array}{l}\text { Head } \\
\text { width }\end{array}$ \\
\hline & & & $-\mathrm{mg}$ & eed & 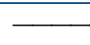 & $9-$ & $d$ & $\longrightarrow$ & 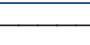 \\
\hline \multicolumn{10}{|l|}{ Group 1} \\
\hline 1219 & Guinea-bicolor & China & 41.1 & 42.6 & 19.6 & 1.9 & 60.8 & 25.0 & 18.2 \\
\hline 1233 & Bicolor & China & 46.8 & 39.0 & 11.7 & 1.6 & 54.3 & 30.1 & 22.1 \\
\hline 16382 & Guinea & Cameroon & 46.3 & 23.0 & 11.1 & 3.2 & 58.3 & 30.3 & 11.3 \\
\hline 23992 & Caudatum & Yemen & 41.8 & 32.5 & 12.2 & 3.0 & 60.2 & 25.9 & 17.1 \\
\hline 28313 & Durra-caudatum & Yemen & 48.6 & 29.2 & 12.2 & 2.9 & 51.5 & 16.0 & 5.0 \\
\hline 28389 & Durra-caudatum & Yemen & 41.2 & 25.7 & 15.7 & 2.8 & 62.4 & 18.4 & 6.5 \\
\hline 28849 & Durra-caudatum & Yemen & 40.3 & 32.1 & 15.4 & 3.2 & 52.0 & 19.1 & 6.5 \\
\hline 30450 & Caudatum-bicolor & China & 42.8 & 34.3 & 16.4 & 2.4 & 62.6 & 19.2 & 8.6 \\
\hline 30460 & Caudatum & China & 35.4 & 33.5 & 25.0 & 2.3 & 62.4 & 19.5 & 9.8 \\
\hline 30507 & Caudatum-bicolor & Korea & 40.8 & 32.8 & 17.0 & 2.0 & 62.4 & 26.4 & 13.0 \\
\hline \multicolumn{10}{|l|}{ Control } \\
\hline 18758 & Guinea-caudatum & Ethiopia & 29.6 & 17.6 & 29.7 & 2.5 & 71.0 & 16.0 & 6.3 \\
\hline 2205 & Durra-bicolor & India & 29.8 & 25.7 & 26.2 & 2.0 & 80.3 & 15.2 & 5.9 \\
\hline 33844 & Durra & India & 26.4 & 22.5 & 35.3 & 3.4 & 77.6 & 14.1 & 6.5 \\
\hline Trial mean & & & 37.0 & 27.0 & 17.0 & 2.6 & 60.6 & 21.0 & 8.3 \\
\hline $\mathrm{SE}( \pm)$ & & & 3.5 & 2.5 & 2.5 & 0.2 & 1.4 & 0.9 & 0.9 \\
\hline LSD (0.05) & & & 9.7 & 6.9 & 6.8 & 0.5 & 3.8 & 2.6 & 2.4 \\
\hline CV (\%) & & & 23.4 & 22.3 & 30.9 & 15.9 & 5.3 & 10.3 & 23.1 \\
\hline \multicolumn{10}{|l|}{ Group 2} \\
\hline 602 & Bicolor & Med sta & 41.9 & 36.2 & 14.2 & 1.3 & 66.8 & 21.3 & 9.1 \\
\hline 1212 & Kafir-bicolor & China & 43.6 & 38.2 & 16.1 & 2.3 & 62.7 & 28.0 & 18.5 \\
\hline 17980 & Durra & India & 35.5 & 35.1 & 16.1 & 1.8 & 66.7 & 20.7 & 7.0 \\
\hline 19859 & Durra & India & 37.6 & 33.1 & 19.2 & 2.7 & 64.9 & 14.2 & 5.8 \\
\hline 20743 & Bicolor & United States & 45.2 & 29.8 & 15.2 & 1.8 & 62.7 & 28.1 & 15.5 \\
\hline
\end{tabular}


Table 4. Continued.

\begin{tabular}{|c|c|c|c|c|c|c|c|c|c|}
\hline $\begin{array}{l}\text { Accession } \\
\text { (IS) }\end{array}$ & Race & Origin & $\mathrm{Fe}$ & $\mathrm{Zn}$ & $\begin{array}{l}\text { Seed } \\
\text { yield }\end{array}$ & $\begin{array}{c}100 \text {-seed } \\
\text { weight }\end{array}$ & $\begin{array}{c}\text { Days } \\
\text { to } 50 \% \\
\text { flowering }\end{array}$ & $\begin{array}{l}\text { Head } \\
\text { length }\end{array}$ & $\begin{array}{l}\text { Head } \\
\text { width }\end{array}$ \\
\hline & & & $-m s$ & eed & $\longrightarrow$ & $9-$ & $d$ & $\longrightarrow$ & $\longrightarrow$ \\
\hline \multicolumn{10}{|c|}{ Group 2, Continued } \\
\hline 21645 & Guinea & Malawi & 44.2 & 30.0 & 10.4 & 1.6 & 66.8 & 20.8 & 9.8 \\
\hline 21863 & Bicolor & Syria & 43.9 & 27.1 & 16.9 & 2.5 & 62.0 & 22.8 & 9.6 \\
\hline 27786 & Durra-bicolor & Morocco & 48.9 & 33.6 & 12.7 & 2.3 & 59.3 & 19.2 & 8.5 \\
\hline 28451 & Guinea-caudatum & Yemen & 38.7 & 32.4 & 13.5 & 2.5 & 63.3 & 19.5 & 11.5 \\
\hline 28747 & Durra-caudatum & Yemen & 44.2 & 29.8 & 17.6 & 2.5 & 67.8 & 18.0 & 7.0 \\
\hline 30383 & Caudatum-bicolor & China & 46.3 & 40.3 & 15.9 & 2.0 & 64.9 & 30.3 & 19.6 \\
\hline 30466 & Caudatum-bicolor & China & 39.4 & 33.1 & 16.9 & 2.0 & 60.8 & 25.7 & 16.3 \\
\hline 30508 & Caudatum-bicolor & Korea & 43.8 & 31.0 & 15.5 & 1.9 & 65.4 & 24.6 & 12.0 \\
\hline 30536 & Caudatum-bicolor & Korea & 39.5 & 36.4 & 16.4 & 1.6 & 64.3 & 36.1 & 16.8 \\
\hline 31651 & Caudatum & Zaire & 43.2 & 33.1 & 23.5 & 2.3 & 71.8 & 17.9 & 6.8 \\
\hline 31681 & Bicolor & Algeria & 46.2 & 29.1 & 12.3 & 1.6 & 66.4 & 18.7 & 6.7 \\
\hline \multicolumn{10}{|l|}{ Control } \\
\hline 18758 & Guinea-caudatum & Ethiopia & 32.9 & 18.7 & 27.3 & 2.4 & 69.4 & 16.2 & 6.8 \\
\hline 2205 & Durra-bicolor & India & 30.1 & 23.9 & 24.4 & 2.1 & 80.3 & 15.3 & 6.3 \\
\hline 33844 & Durra & India & 26.5 & 22.2 & 33.5 & 3.6 & 77.3 & 14.7 & 6.9 \\
\hline Trial mean & & & 35.5 & 26.6 & 21.4 & 2.4 & 67.7 & 20.4 & 8.8 \\
\hline $\mathrm{SE}( \pm)$ & & & 3.6 & 2.9 & 2.1 & 0.2 & 1.5 & 0.9 & 1.0 \\
\hline LSD (0.05) & & & 10.0 & 8.2 & 5.8 & 0.5 & 4.1 & 2.5 & 2.9 \\
\hline CV (\%) & & & 24.8 & 27.0 & 24.1 & 17.0 & 5.4 & 10.5 & 28.9 \\
\hline \multicolumn{10}{|l|}{ Group 3} \\
\hline 5301 & Guinea-caudatum & United States & 38.8 & 32.2 & 15.4 & 1.6 & 78.0 & 19.8 & 10.7 \\
\hline 8774 & Kafir-durra & South Africa & 41.9 & 32.4 & 24.0 & 2.1 & 66.7 & 24.6 & 6.4 \\
\hline 24503 & Bicolor & South Africa & 48.5 & 32.8 & 1.0 & 0.4 & 73.3 & 32.9 & 22.8 \\
\hline \multicolumn{10}{|l|}{ Control } \\
\hline 18758 & Guinea-caudatum & Ethiopia & 33.9 & 18.6 & 26.7 & 2.3 & 69.5 & 16.3 & 7.0 \\
\hline 2205 & Durra-bicolor & India & 30.7 & 24.9 & 26.3 & 2.1 & 80.3 & 15.3 & 6.3 \\
\hline 33844 & Durra & India & 28.9 & 23.0 & 36.0 & 3.5 & 77.3 & 15.0 & 7.0 \\
\hline Trial mean & & & 34.5 & 24.7 & 23.7 & 2.4 & 75.3 & 21.9 & 8.7 \\
\hline Trial range & & & & & & & & & \\
\hline $\operatorname{SE}( \pm)$ & & & 3.5 & 2.5 & 2.3 & 0.1 & 1.8 & 1.0 & 1.1 \\
\hline LSD (0.05) & & & 9.7 & 7.0 & 6.3 & 0.4 & 5.1 & 2.7 & 2.9 \\
\hline CV (\%) & & & 24.9 & 25.0 & 23.5 & 14.1 & 5.9 & 11.0 & 29.9 \\
\hline \multicolumn{10}{|l|}{ Group 4} \\
\hline 4951 & Guinea & India & 41.9 & 33.8 & 14.2 & 1.6 & 82.8 & 29.9 & 14.7 \\
\hline 25249 & Durra-bicolor & Ethiopia & 40.2 & 32.8 & 16.5 & 1.5 & 91.3 & 28.4 & 24.4 \\
\hline \multicolumn{10}{|l|}{ Control } \\
\hline 18758 & Guinea-caudatum & Ethiopia & 34.1 & 18.6 & 25.5 & 2.2 & 70.3 & 16.8 & 6.6 \\
\hline 2205 & Durra-bicolor & India & 31.5 & 25.2 & 23.8 & 2.1 & 80.1 & 15.5 & 6.4 \\
\hline 33844 & Durra & India & 27.5 & 23.0 & 40.8 & 3.6 & 77.5 & 15.5 & 6.4 \\
\hline Trial mean & & & 34.0 & 26.0 & 23.5 & 2.3 & 83.8 & 21.8 & 8.8 \\
\hline $\operatorname{SE}( \pm)$ & & & 3.4 & 2.6 & 2.3 & 0.1 & 1.9 & 1.0 & 1.0 \\
\hline LSD (0.05) & & & 9.4 & 7.3 & 6.3 & 0.3 & 5.4 & 2.7 & 2.9 \\
\hline CV (\%) & & & 24.3 & 24.4 & 25.1 & 12.1 & 5.6 & 10.9 & 28.7 \\
\hline \multicolumn{10}{|l|}{ Group 5} \\
\hline 24139 & Guinea & Tanzania & 43.3 & 34.3 & $13.7 w$ & 1.7 & 95.0 & 31.7 & 14.7 \\
\hline 24175 & Guinea & Tanzania & 36.7 & 32.3 & 13.1 & 1.9 & 97.7 & 32.7 & 19.2 \\
\hline 24218 & Guinea & Tanzania & 38.8 & 32.9 & 21.8 & 3.2 & 104.7 & 31.2 & 17.8 \\
\hline \multicolumn{10}{|l|}{ Control } \\
\hline 18758 & Guinea-caudatum & Ethiopia & & 18.7 & 27.9 & s. & 69.3 & 17.5 & 6.4 \\
\hline 2205 & Durra-bicolor & India & 31.8 & 25.4 & 27.1 & 2.1 & 80.8 & 16.7 & 6.6 \\
\hline 33844 & Durra & India & 27.7 & 22.8 & 42.4 & 3.5 & 77.3 & 15.0 & 6.6 \\
\hline Trial mean & & & & & & & 90.3 & 23.8 & 9.7 \\
\hline $\operatorname{SE}( \pm)$ & & & & 2.4 & 3.3 & 0.1 & 2.8 & 0.9 & 1.2 \\
\hline LSD (0.05) & & & 10.5 & 6.7 & 9.2 & 0.4 & 7.7 & 2.4 & 3.5 \\
\hline CV (\%) & & & 27.1 & 22.6 & 35.1 & 15.5 & 7.5 & 8.9 & 31.2 \\
\hline
\end{tabular}



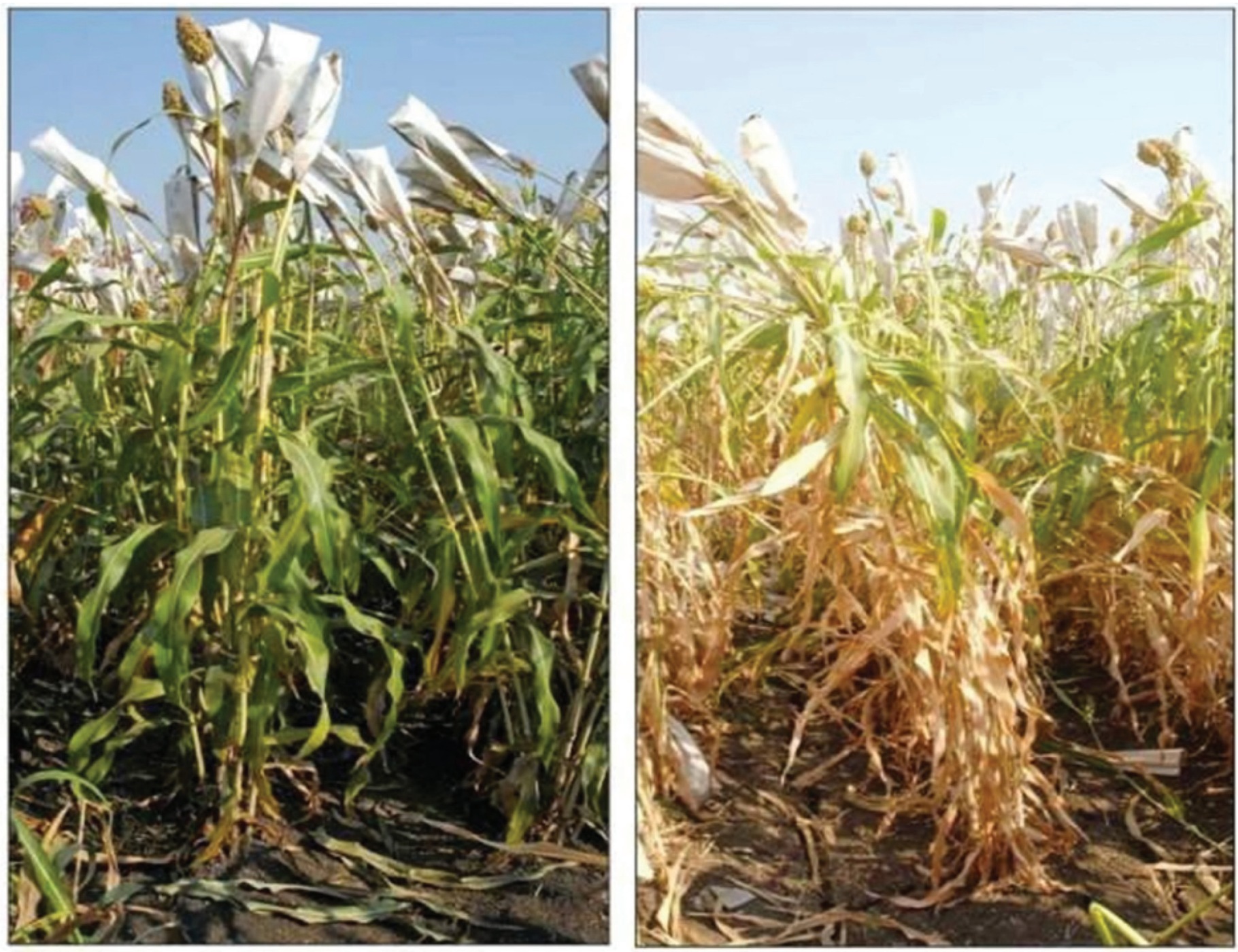

Figure 1. A representative accession (IS 25836) under irrigated (left) and imposed terminal drought (right) conditions at experimental plot in India.

groups. A comparison of magnitude of variance or its significance in relation to standard error indicate the relative importance of main and interaction effects on trait expression. Pooled analysis indicate greater importance of $\sigma^{2}{ }_{g}$ than that of $\sigma^{2}{ }_{g \times d \times y}$ interaction for days to $50 \%$ flowering, head length (except in Group 1 and 4), head width, seed yield, 100-seed weight, and Fe and Zn (except for Group 1 and 4) concentration in Groups 1 to 4 (Table 1). For Fe in Group 3, $\sigma^{2} \times \mathrm{d} \times \mathrm{y}$ was greater than that of $\sigma_{\mathrm{g}}^{2}$. Group 2 and Group 3 accessions were more variable for days to $50 \%$ flowering, head length and head width, seed yield, 100-seed weight, and seed $\mathrm{Fe}$ and $\mathrm{Zn}$ concentration than those of Group 1 and Group 4. Group 5 was least variable for these traits. For days to $50 \%$ flowering, $\sigma^{2}$ gxy was of greater importance than that of $\sigma_{\mathrm{g} \times \mathrm{d} \times \mathrm{y}}$ in Groups 1 to 4 (Table 1). Compared with irrigated environments, drought stress significantly increased both seed $\mathrm{Fe}$ and $\mathrm{Zn}$ concentration in Groups 1 to 4 (Table 2). Publishedresearch in the literature have reported increased $\mathrm{Fe}$ and $\mathrm{Zn}$ concentration under drought stress in crops including barley, lupin
(Lupinus albus L.), maize, pearl millet (Pennisetum glaucum L.), rice, and wheat (Carvalho, 2005; Crusciol et al., 2008; Zhao et al., 2009; Rastija et al., 2010; Farahani et al., 2011; Kandianis et al., 2013), and this contrasts with the reports that reported no effect of drought on mean seed Fe and $\mathrm{Zn}$ in wheat (Feil et al., 2005; Peleg et al., 2008) or reported reduced mean seed $\mathrm{Fe}$ and $\mathrm{Zn}$ under drought stress in sweet corn (Oktem, 2008; Kandianis et al., 2013).

The movement of mineral elements from soils to seeds involves their mobilization in soils, uptake by roots, translocation to the shoots, and redistribution within the plant and deposition in seeds (Grusak and DellaPenna, 1999; White and Broadley, 2009). Further, the accumulation of nutrients including seed $\mathrm{Fe}$ and $\mathrm{Zn}$ for yield formation during the maturity stage take place as a result of translocation of nutrients from nonstoring plant parts (such as stem and leaves) to the seed. What probably contributed to enhanced seed Fe and $\mathrm{Zn}$ concentration under drought-stressed environment in the present study? A close examination of trends in seed yield and 
100 -seed weight in relation to $\mathrm{Fe}$ and $\mathrm{Zn}$ concentration in seed revealed significant increase in $\mathrm{Fe}$ and $\mathrm{Zn}$ and a corresponding decrease in seed yield in Group 2 and 3, while in Group 1 and 4, although $\mathrm{Fe}$ and $\mathrm{Zn}$ increased significantly, corresponding significant decrease in seed yield was not observed (Table 2). Interestingly, there was no change in 100-seed weight under irrigated and drought-stressed environments in any group. Such differences in yield and concentration probably could be explained, respectively, by concentration effect in Groups 2 and 3 and synergism in Groups 1 and 4 (for detailed discussion see Jarrell and Beverly, 1981).

\section{Rank Correlations and its Significance}

The proportion of variance in one trait that can be attributed to its relationship with the other trait is indicated by its coefficient of determination (Snedecor and Cochran, 1980). The correlation coefficients with absolute value greater than 0.71 , which account for $50 \%$ phenotypic variation, is suggested meaningful (Skinner et al., 1999). A highly significant and positive rank correlation $(\geq 0.70$ in 27 of the 29 combinations) between irrigated and droughtstressed environments means that the accessions with high seed Fe and $\mathrm{Zn}$ concentrations (or even for high seed yield and 100-seed weight) under irrigated environment, for example, are expected to perform well under droughtstressed environment as well (Table 3). Further, positive correlations between $\mathrm{Fe}$ and $\mathrm{Zn}$ under both irrigated and drought-stressed environments indicate that simultaneous improvement in the seed $\mathrm{Fe}$ and $\mathrm{Zn}$ is possible by selecting for one of them. This also suggests a common genetic-physiological mechanism for the two elements in terms of mineral uptake by the root system, translocation, redistribution within the plant tissues, remobilization to the seed, and accumulation in the developing seed (Chatzav et al., 2010). Seed Fe and Zn concentrations, however, were either not correlated or had low to moderate correlation ( $\mathrm{Fe}$ and $\mathrm{Zn}$ with seed yield: $-0.24[p<0.05]$ to -0.60 [ $p<0.001]$; Fe and $\mathrm{Zn}$ with 100 -seed weight: $-0.31[p<0.05]$ to $-0.64[p<0.001])$ with seed yield and 100-seed weight (Table 3). An earlier study on sorghum also reported significant positive correlation between seed $\mathrm{Fe}$ and $\mathrm{Zn}$, and seed $\mathrm{Fe}$ and $\mathrm{Zn}$ were negatively correlated with seed yield and 100-seed weight (Kumar et al., 2012). In the present study, six (IS 1004, 23514, 23579, 23590, 28141, and 31706) and four (IS 1004, 27034, 28141, and 31706) accessions, respectively, showed 8 to $39 \%$ and 9 to $38 \%$ greater $\mathrm{Fe}$ and $\mathrm{Zn}$ over IS 33844 and produced seed yields similar to that of IS 33844 . This suggests that it might be possible to break undesirable association (as observed in the present study between seed yield and $\mathrm{Fe}$ and $\mathrm{Zn}$ concentrations) through recombination breeding, thus allowing researchers to combine high $\mathrm{Fe}$ and $\mathrm{Zn}$ into high-yielding genetic backgrounds.

\section{Variability and Identification of Diverse Germplasm}

Across environments (irrigated and drought-stressed), about twofold variation for seed Fe (25.8-48.9, average $35 \mathrm{mg} \mathrm{kg}^{-1}$ seed) and about threefold variation for seed Zn (13.5-42.6, average $25.8 \mathrm{mg} \mathrm{kg}^{-1}$ seed) was observed (Supplementary Table S1), which is in accord with the results reported in the published literature (Carvalho, 2005; Crusciol et al., 2008; Zhao et al., 2009; Rastija et al., 2010; Farahani et al., 2011; Kandianis et al., 2013), although the variation is less than that reported by Kayodé et al. (2006) for Fe (30-113 $\mathrm{mg} \mathrm{kg}^{-1}$ seed) among 76 farmer-preferred cultivars from northern Benin. The performance of controls IS 18758 (Fe) and IS 2205 (Zn) in this study across environments were the best in each maturity group for seed Fe (29.6-34.1 $\mathrm{mg} \mathrm{kg}^{-1}$ seed) and Zn (23.9-25.7 $\mathrm{mg} \mathrm{kg}^{-1}$ seed). Eleven accessions with high $\mathrm{Fe}, 14$ accessions with high $\mathrm{Zn}$, and nine accessions high in both $\mathrm{Fe}$ and $\mathrm{Zn}$ were identified (Table 4). These accessions, except for IS 24503, produced seed yield of 29 to $69 \%$ of the highest yielding control IS 33844 (seed yield 33.5-42.4 g plant $^{-1}$ ). Genetically diverse germplasm pairs identified in the present study may be crossed to broaden the genetic base and selecting for seed nutrient-dense (Fe and $\mathrm{Zn}$ ) cultivars. Germplasm collections at ICRISAT are available under the terms and conditions of the Standard Materials Transfer Agreement of the International Treaty on Plant Genetic Resources for Food and Agriculture (http://10.3.1.36:8080/what-we-do/crops/SMTA.pdf).

\section{Seed Iron- and Zinc-Dense Germplasm Resistant to Pest and Diseases}

Sorghum is adversely impacted by diseases and pests (House, 1985; Sharma, 1993). A number of accessions identified in the present study as dense in seed Fe and Zn were earlier also reported resistant to major pest and diseases in sorghum (Supplementary Table S3). For example, IS 23992 is resistant to downy mildew and grain mold (Sharma et al., 2010, 2012), IS 24503 to leaf blight and rust (Sharma et al., 2012), IS 1233 to shoot fly and stem borer (http://www.icrisat.org/ what-we-do/crops/sorghum/Project1/pfirst.asp), IS 28449, 28747, 30383, and 30466 to downy mildew (Sharma et al., 2010; Radwan et al., 2011), IS 5301 and 24218 to anthracnose and IS 30536 and 31681 to grain mold (Sharma et al., 2012), and IS 28451 to shoot fly (http://www.icrisat.org/ what-we-do/crops/sorghum/Project1/pfirst.asp).

\section{CONCLUSIONS}

Drought stress in relation to irrigated control significantly increased mean seed $\mathrm{Fe}$ and $\mathrm{Zn}$ concentrations. A highly significant $D, Y$, and $D \times Y$ interaction emphasizes the need to have multienvironment evaluations for identifying seed $\mathrm{Fe}$ - and $\mathrm{Zn}$-dense germplasm. Genotypes differed significantly for seed $\mathrm{Fe}$ and $\mathrm{Zn}$ concentrations and for 
agronomic traits. A number of germplasm lines with significantly greater seed $\mathrm{Fe}$ and $\mathrm{Zn}$ across environments were identified; however, invariably these were low yielders. High significant and positive rank correlation between irrigated and drought-stressed environments suggests that performance of the accessions in one environment could probably be indicative of performance in the other. Furthermore, a positive and significant correlation between Fe and $\mathrm{Zn}$ suggests that simultaneous improvement might be effective in breeding programs.

\section{References}

Assefa, Y., S.A. Staggenborg, and V.P.V. Prasad. 2010. Grain sorghum requirement and responses to drought stress: A review. Crop Manage. 9. doi:10.1094/CM-2010-1109-01-RV.

Billot, C., P. Ramu, S. Bouchet, J. Chantereau, M. Deu, L. Gardes, J.L. Noyer, J.F. Rami, R. Rivallan, Y. Li, P. Lu, T. Wang, R.T. Folkertsma, E. Arnaud, H.D. Upadhyaya, J.C. Glaszmann, and C.T. Thomas. 2013. Massive sorghum collection genotyped with SSR markers to enhance use of global genetic resources. PLoS ONE 8:e59714. doi:10.1371/journal.pone.0059714

Bouis, H.E. 2003. Micronutrient fortification of plants through plant breeding: Can it improve nutrition in man at low cost? Proc. Nutr. Soc. 62:403-411. doi:10.1079/PNS2003262

Cakmak, I. 2008. Enrichment of cereal grains with zinc: Agronomic or genetic biofortification? Plant Soil 302:1-17. doi:10.1007/ s11104-007-9466-3

Carvalho, I.M.M.S. 2005. Effect of water stress on the proximate composition and mineral contents of seeds of two lupins (Lupinus albus and L. mutabilis). J. Food Qual. 28:325-332. doi:10.1111/j.1745-4557.2005.00040.x

Chatzav, M., Z. Peleg, L. Ozturk, A. Yazici, T. Fahima, I. Cakmak, and Y. Saranga. 2010. Genetic diversity for grain nutrients in wild emmer wheat: Potential for wheat improvement. Ann. Bot. (Lond.) 125:529-531.

Crusciol, C.A.C., O. Arf, R.P. Soratto, and G.P. Mateus. 2008. Grain quality of upland rice cultivars in response to cropping systems in the Brazilian tropical Savanna. Sci. Agric. (Piracicaba. Braz.) 65:468-473.

Darnton-Hill, I., P. Webb, P.W. Harvey, J.M. Hunt, N. Dalmiya, M. Chopra, M.J. Ball, M.W. Bloem, and B. de Benoist. 2005. Micronutrient deficiencies and gender: Social and economic cost. Am. J. Clin. Nutr. 81:1198S-1205S.

Dunnett, C.W. 1964. New tables for multiple comparisons with a control. Biometrics 20:482-491. doi:10.2307/2528490

Dwivedi, S.L., K.L. Sahrawat, K.N. Rai, M.W. Blair, M.S. Andersson, and W. Pfeiffer. 2012. Nutritionally enhanced staple food crops. Plant Breed. Rev. 36:169-291.

Dwivedi, S., K. Sahrawat, H. Upadhyaya, and R. Ortiz. 2013. Food, nutrition and agrobiodiversity under global climate change. Adv. Agron. 120:1-128. doi:10.1016/B978-0-12-407686-0.00001-4

El-Swaify, S.A., P. Pathak, T.J. Rigo, and S. Singh. 1985. Soil management for optimized productivity under rainfed conditions in the semi-arid tropics. Adv. Soil Sci. 1:1-64. doi:10.1007/9781-4612-5046-3_1

FAOSTAT. 2013. Production, crops. FAOSTAT, Rome. http://faostat3.fao.org/browse/Q/QC/E (accessed 30 Dec. 2014).T ET T
Farahani, S.M., M.R. Caichi, D. Mazaheri, R.T. Afshari, and G. Savaghebi. 2011. Barley grain mineral analysis as affected by different fertilizing systems and by drought stress. J. Agric. Sci. Technol. 13:315-326.

Feil, B., S.B. Moser, S. Jampatong, and P. Stamp. 2005. Mineral composition of the grains of tropical maize varieties as affected by preanthesis drought and rate of nitrogen fertilization. Crop Sci. 45:516-523. doi:10.2135/cropsci2005.0516

Frankel, O.H. 1984. Genetic perspective of germplasm conservation. In: W. Arber, K. Limensee, W.J. Peacock, and P. Stralinger, editors, Genetic manipulations: Impact on man and society. Cambridge Univ. Press, Cambridge, UK. p. 161-170.

Graham, R.D., and R.M. Welch. 1996. Breeding for staple food crops with high micronutrient density. Working papers on agricultural strategies for micronutrients, No. 3. International Food Policy Research Institute, Washington, DC.

Grusak, M.A., and D. DellaPenna. 1999. Improving the nutrient composition of plants to enhance human nutrition and health. Annu. Rev. Plant Physiol. Plant Mol. Biol. 50:133-161. doi:10.1146/annurev.arplant.50.1.133

House, L.R. 1985. A guide to sorghum breeding. 2nd ed. International Crops Research Institute for the Semi-Arid tropics, Patancheru, India.

IBPGR and ICRISAT. 1993. Descriptors for sorghum [Sorghum bicolor (L.) Moench]. Int. Board for Plant Genetic Resources, Rome, Italy; ICRISAT, Patancheru, India.

Jarrell, W.M., and R.B. Beverly. 1981. The dilution effect in plant nutrition studies. Adv. Agron. 34:197-224. doi:10.1016/S00652113(08)60887-1

Kandianis, C.B., A.S. Michenfelder, S.J. Simmons, M.A. Grusak, and A.E. Stapelton. 2013. Abiotic stress growth conditions induce different responses in kernel iron concentration across genotypically distinct maize inbred varieties. Front. Plant Sci. 4:488. doi:10.3389/fpls.2013.00488

Kayodé, A.P.P., A.R. Linnemann, J.D. Hounhouigan, M.J.R. Nout, and M.A.J.S. van Boekel. 2006. Genetic and environmental impact on iron, zinc, and phytate in food sorghum grown in Benin. J. Agric. Food Chem. 54:256-262. doi:10.1021/ jf0521404

Kholová, J., G. McLean, V. Vadez, P. Craufurd, and G.L. Hammer. 2012. Drought stress characterization of post-rainy (rabi) sorghum in India. Field Crops Res. 141:38-46. doi:10.1016/j. fcr.2012.10.020

Kumar, A.A., B.V.S. Reddy, B. Ramaiah, K.L. Sahrawat, and W.H. Pfeiffer. 2012. Genetic variability and character association for grain iron and zinc contents in sorghum germplasm accessions and commercial cultivars. Eur. J. Plant Sci. Biotechnol. 6:66-70.

Lindsay, W.L., and W.L. Norvell. 1978. Development of a DTPA test for zinc, iron, manganese and copper. Soil Sci. Soc. Am. J. 42:421-428. doi:10.2136/sssaj1978.03615995004200030009x

Oktem, A. 2008. Effect of water shortage on yield, and protein and mineral compositions of drip-irrigated sweet corn in sustainable agricultural systems. Agric. Water Manage. 95:1003-1010. doi:10.1016/j.agwat.2008.03.006

Patterson, H.D., and R. Thompson. 1971. Recovery of inter block information when block sizes are unequal. Biometrika 58:545554. doi:10.1093/biomet/58.3.545

Peleg, Z., Y. Saranga, A. Yazici, T. Fahima, L. Ozturk, and I. Cakmak. 2008. Grain zinc, iron and protein concentrations and zinc-efficiency in wild emmer wheat under contrasting irrigated regimes. Plant Soil 306:57-67. doi:10.1007/s11104-007-9417-z 